\title{
REFLEXIONES JURÍDICO- CONSTITUCIONALES SOBRE LA OBJECIÓN DE CONCIENCIA Y LOS TRATAMIENTOS MÉDICOS
}

\author{
YOLANDA GÓMEZ SÁNCHEZ
}

Profesora Titular de Derecho Constitucional

UNED 


\section{SUMARIO}

I. AlgunAs NOtAS SOBRE EL ESTATUTO CONSTITUCIONAL DE LA OBJECIÓN DE CONCIENCIA. I.1. La libertad como fundamento de los derechos constitucionales. 1.2. Concepto jurídico-constitucional de objeción de conciencia. II. STATUS CONSTITUCIONAL DE LA OBJECIÓN DE CONCIENCIA AL SERVICIO MILITAR Y EL DE LAS OTRAS OBJECIONES DE CONCIENCIA. II.1. La objeción de conciencia ¿derecho o exención de un deber? II.2. El sujeto de la objeción de conciencia. III. OBJECIÓN DE CONCIENCIA Y TRATAMIENTOS MÉDICOS INDIVIDUALES EN EL ORDENAMIENTO CONSTITUCIONAL. III.1. Objeción de conciencia a tratamientos médicos: tipos. III.2. Tratamientos médicos en persona adulta y capaz. III.3. Tratamientos médicos en persona adulta incapaz. III.4. Tratamientos médicos en menores de edad. III.5. Asistencia hospitalaria conforme a distintas conviciones religiosas. IV. LA OBJECIÓN DE CONCIENCIA A TRATAMIENTOS MÉDICOS EN SITUACIONES DE RIESGO COLECTIVO. 


\section{REFLEXIONES JURÍDICO- CONSTITUCIONALES SOBRE LA OBJECIÓN DE CONCIENCIA Y LOS TRATAMIENTOS MÉDICOS}

POR

YOLANDA GÓMEZ SÁNCHEZ

Profesora Titular de Derecho Constitucional

UNED

\section{ALGUNAS OBJECIONES SOBRE EL ESTATUTO CONSTITUCIONAL DE LA OBJECIÓN DE CONCIENCIA}

\section{I.1. La libertad como fundamento de los derechos constitucionales ${ }^{1}$}

La lucha por la libertad ha marcado la historia de la Humanidad y esa reivindicación secular se encuentra en la base misma de la transformación operada en los Estados absolutistas hasta configurarse como Estados democráticos. Definir la libertad, como afirma R. SÁNCHEZ FERRIZ², es

1 Utilizaremos en estas páginas el término derecho constitucional para referirnos a cualquiera de los derechos expresamente regulados en la Constitución Española de 1978 y el de derecho fundamental para citar los derechos constitucionales que reciben las máximas garantías que la Constitución otorga, en concreto, y como ha confirmado el Tribunal Constitucional, son derechos fundamentales los incluidos en la Sección 1. ${ }^{\mathrm{a}}$, del Capítulo II, del Título I (arts. 15 a 29).

2 Sánchez Ferriz, R.: Estudios sobre las libertades, Tirant lo Blanch, Valencia, 2." ed., 1995, pág. 55. 
sumamente difícil ya que se trata de una vivencia humana, aunque sí puede afirmarse que la libertad es la base sobre la que descansa el reconocimiento y tutela de los demás derechos humanos. En última instancia se trata de reconocer que el poder debe frenar sus impulsos ante determinados ámbitos humanos.

Así, la dimensión democrática de la libertad permite, por un lado, el desarrollo del sujeto tanto individualmente como a través de los grupos en los que se integra y, por otro lado, su participación en los asuntos públicos a través de las libertades políticas ${ }^{3}$. Tiende así la libertad a completar los dos grandes ámbitos de la vida del hombre: lo público y lo privado; lo personal y lo social. Pero la libertad no se presenta en el marco estatal en abstracto sino que se diversifica en un conjunto de derechos y de libertades (libertad religiosa e ideológica, libertad de expresión, derecho de participación, derecho de reunión, derecho a la educación....) ${ }^{4}$, a través de los cuales se intenta cumplir con la aspiración secular de hacer compatible la autonomía individual con las necesidades de la colectividad ${ }^{5}$.

En este marco, los derechos y libertades representan hoy una esfera de la vida del sujeto en la cual éste es soberano y actúa libremente, a la vez que dicho ámbito queda protegido de intromisiones de los poderes públicos y de las acciones de otros sujetos. Los derechos y libertades, son, pues, concreciones del valor libertad, y, por ello, «a diferencia de la libertad en abstracto, precisan de una clara determinación de su ámbito y alcance por cuanto constituyen zonas concretas de autonomía en las que se desenvuelven las voluntades individuales» ${ }^{6}$. En este contexto, la Constitución, como norma que vertebra el Ordenamiento jurídico, al regular los distintos derechos y libertades señala el espacio indisponible para el legislador ordinario y dota a estos preceptos, en sistema jurídicos como el nuestro, de un conjunto de garantías que permiten el libre ejercicio de los

3 lbidem.

4 Aunque se ha extendido el uso indiferenciado de los términos derecho y libertad, originariamente ésta designaba esferas de autonomía del sujeto ante las que el Estado debia simplemente abstenerse, mientras que el término derecho aludia a una demanda concreta del individuo frente a ese mismo Estado que, para hacerlo efectivo, podía resultar obligado a determinada actuación. La posterior consolidación de los derechos de prestación ha diluido aun más la diferenciación inicial.

5 La Constitución Española, en su artículo 1.1, califica a la libertad -junto con la justicia, la igualdad y el pluralismo político - como valor superior del Ordenamiento jurídico; libertad que, tal y como hemos señalado, se explicita a lo largo del texto constitucional -en especial en el Título Ien una amplio catálogo de derechos y libertades concretos.

6 SÁnchez Ferriz, R.: Estudio sobre las libertades, ob. cit., pág. 59. 
mismos. El Ordenamiento constitucional, además, puede graduar dichas garantías otorgando a un grupo de derechos el máximo nivel de protección como así hace la Constitución española con los derechos fundamentales comprendidos en la Sección 1.a , del Capítulo II, del Título I (arts. 15 a 29) y extendiendo estas superiores garantias - salvo la reserva de ley orgánica- al artículo 14 (igualdad) y al artículo 30.2 (objeción de conciencia al servicio militar) ${ }^{7}$.

Por otro lado, existe hoy un cierto consenso en torno al catálogo de derechos propios de una sociedad democrática, pero este elenco se ha formado a través de la incorporación sucesiva de derechos y libertades nacidos al calor de reivindicaciones populares, a veces, de élites en otros casos ${ }^{8}$. Además, la incorporación de muchos Estados actuales, entre ellos el nuestro, a organizaciones supranacionales permite, cuando dicha incorporación incide en materia de derechos y libertades, una interpretación homogénea de los mismos cuando no la incorporación de nuevos derechos ${ }^{9}$. En 1978, los constituyentes optaron, finalmente, por incluir en su texto un amplio número de derechos y libertades en el que, junto a derechos clásicos (derecho a la vida, libertad de expresión, libertad ideológica y religiosa, derecho a la educación ....), figuran otros que se han incorporado posteriormente al constitucionalismo europeo (derechos sociales, laborales, protección del medio ambiente ....), pero, además, la fuerza expansiva de los derechos alienta el reconocimiento de otros nuevos o de aspectos inéditos en derechos ya conocidos. Este es el caso de las más recientes demandas en torno al reconocimiento y subsiguiente regulación de objeciones de conciencia distintas de la ya reconocida al servicio militar.

7 El Tribunal Constitucional ha señalado, como no podía ser de otra manera (STC 120/1990, de 27 de junio), que la garantia del recurso de amparo procede exclusivamente en los casos en los que la Constitución ha otorgado dicha protección y no es aplicable esta garantía última a reivindicaciones genéricas de la libertad como valor superior del Ordenamiento juridico que, sí, sin embargo, pueden fundamentar un recurso de inconstitucionalidad. Cosa distinta es cuál sea el alcance de la libertad personal reconocida en el artículo 17.1 de la Constitución que era realmente el aspecto discutido en la Sentencia citada (Caso de los miembros del GRAPO en huelga de hambre).

8 Tanto es así que la doctrina ha dividido y clasificado los derechos en generaciones. Cfr. Bobbio, N.: El Tiempo de los Derechos, Sistema, Madrid, 1991. Cassese, A.: Los derechos humanos en el mundo contemporáneo, Ariel, Barcelona, 1993. FreIXEs, T.: Constitución y derechos fundamentales, PPU, Barcelona, 1992. PeCEs BARBA, G.: Curso de Derecho fundamentales (I), Eudema, Madrid, 1991. SÁnChEz FERRIz, R.: Estudio sobre las libertades, ob. cit.

9 La Constitución Española carece de un artículo que expresamente permita la incorporación de nuevos derechos al inicial catálogo como sí lo tenía la Constitución de 1869 (art. 29). 


\section{I.2. Concepto jurídico-constitucional de objeción de conciencia ${ }^{10}$}

Al tratar de abordar el problema de la objeción de conciencia, resulta inexcusable señalar que se trata de una demanda estrechamente ligada a la libertad de conciencia "1, que se expresa en la libertad religiosa e ideológica reconocidas, en nuestro Ordenamiento, en el artículo 16 de la Constitución ${ }^{12}$. Aunque no podemos en estas breves páginas extendernos en el análisis de estas libertades ${ }^{13} \mathrm{si}$, quizá, pueda afirmarse que la libertad religiosa e ideológica tutelan el ámbito más específico de la identidad humana, "el lugar en donde cada ser humano busca y establece su relación personal con los valores" ${ }^{14}$ con los que cada ser humano quiere comprometerse. El respeto a esta esfera de autonomía define una de las características esenciales del Estado democrático que no puede entenderse exclusivamente como ausencia de coacción sobre el individuo en materia religiosa o ideológica sino que también implica la prohibición de que el Estado influya sobre la formación y existencia de aquellas convicciones ${ }^{15}$.

La libertad religiosa permite al individuo profesar una determinada religión, manifestarla individual o colectivamente, en público o en privado y realizar el culto inherente a la misma. La libertad ideológica consiste, por otro lado, en la posibilidad de adoptar y vivir conforme una determinada ideología, entendiendo por tal «toda concepción del mundo destinada a la acción, esto es, se trata de un sistema relativamente coherente de creencias que los

10 Un estudio general sobre la objeción de conciencia en la Constitución Española en: Escobar Roca, G.: La objeción de conciencia en la Constitución Española, Centro de Estudios Constitucionales, Madrid, 1993.

11 SORIANo, R.: «La objeción de conciencia: significado, fundamentos jurídicos y positivación en el ordenamiento jurídico español», Revista de Estudios Políticos, 58 (1987), pág. 62.

12 Un sector doctrinal considera con acierto que la libertad de conciencia o de creencias abarca tanto la libertad religiosa como la libertad ideológica EsTEBAN, J. DE; GoNZÁLEZ TREVIJANo, P.J.: Curso de Derecho Constitucional Español, Vol. II, Servicio de Publicaciones de la Facultad de Derecho, Universidad Complutense, Madrid, 1993. PeCes Barba MARTinez, G.: «Algunas reflexiones sobre la libertad ideológica y religiosa", en IBAN, I.C.: Libertad y derecho fundamental de libertad religiosa Ed. RDP/Edersa, Madrid, 1989. En contra, GONZÁlez ENCINAR, J.J.: «Prólogo" del libro de EscobaR RocA, G.: La objeción de conciencia en la Constitución Española, ob. cit., pág. 31.

13 El artículo 16.1 de la Constitución Española dice: "Se garantiza la libertad ideológica, religiosa y de culto de los individuos y las comunidades sin más limitación en sus manifestaciones, que la necesaria para el mantenimiento del orden público protegido por la ley."

14 BENEYTO, J.M.: "Artículo 16. La libertad ideológica y religiosa», en ALZAGA, O.: Comentarios a las Leyes Políticas. Constitución Española de 1978, Edersa, Tomo II, 1984.

15 Serrano Alberca, J.M.: «Artículo 16", en Garrido Falla, F., y otros: Comentarios a la Constitución, 2.. ed., Civitas, Madrid, 1985. pág. 287. 
seres sociales se hacen a sí mismos, de los otros hombres y de la sociedad para orientarse en el mundo, comprenderlo y actuar sobre él» ${ }^{16}$. Por su ubi-

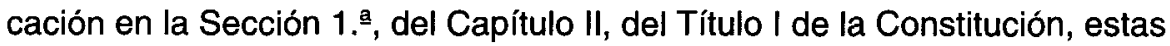
libertades tienen carácter fundamental y por ello reciben las máximas garantías que el Ordenamiento constitucional otorga ${ }^{17}$. Pero las libertades contenidas en el artículo 16, aun siendo fundamentales y como acontece con los demás derechos y libertades constitucionales, no poseen carácter absoluto de tal suerte que prevalezcan ante cualquier situación. Hoy el problema jurídico-constitucional de los derechos y libertades se refiere tanto a su reconocimiento como a sus límites y garantías y, por ello, resulta esencial determinar el alcance de su regulación en el texto constitucional (expreso o inferido de otro derecho o libertad) así como la posición jurídica de los demás derechos y libertades con los que pueda entrar en colisión para determinar su status jurídico.

¿Pero qué es la objeción de conciencia? ${ }^{18}$. Contestar a esta pregunta no resulta tarea fácil como lo ha señalado un amplio sector doctrinal ${ }^{19}$, aunque se han formulado diversas definiciones de objeción de conciencia. Así, R. NAVARRO-VALLS ${ }^{20}$ afirma que la objeción de conciencia es «toda pretensión contraria a la ley motivada por razones axiológicas -

16 Esteban, J. de; Gonzalez Trevijano, P.J.: Curso de Derecho Constitucional Español, Vol. II, ob. cit., pág. 59.

17 De conformidad con el artículo $53 \mathrm{CE}$, además de la reserva de ley orgánica, el respeto de su contenido esencial, la vinculación de los poderes públicos y la necesidad de reforma agravada para su modificación, la Constitución otorga a este grupo de derechos (arts. 15 a 29), la tutela judicial mediante un procedimiento preferente y sumario y, en su caso, a través del recurso de amparo ante el Tribunal Constitucional.

18 Aunque puedan encontrarse precedentes el problema de la objeción de conciencia en España no se remonta más allá de los años setenta y, en otros países cercanos, no es muy anterior. En Francia la primera Ley sobre objeción de conciencia es de 1963. En Italia no hubo regulación hasta 1972 y, en Alemania, la propia Constitución de 1949 ya reconoció esta posibilidad. En el plano europeo la Resolución 337 de 26 de enero de 1967 de la Asamblea del Consejo de Europa fue la que reconoció la objeción de conciencia como un derecho subjetivo derivado de los derechos contenidos en el artículo 9 del Convenio de Roma. En España el artículo 30.2 de la Constitución no tiene precedentes aunque, antes de la llegada de ésta, el problema de la objeción de conciencia al servicio militar ya había aparecido; no se lograron los proyectos de 1970 y 1971 y la Ley 29/1973, de 19 de diciembre, añadió el artículo 383 bis al Código de Justicia Militar eliminando las condenas en cadena. Posteriormente, el Real Decreto 3011/1976, de 23 de diciembre permite aplicar prórrogas por este motivo.

19 Cfr. Escobar Roca, G.: La objeción de conciencia en la Constitución Española, ob. cit., pág. $39 \mathrm{y}$ ss.

20 En VV.AA.: Tratado de Derecho Eclesiástico, Eunsa, Pamplona, 1993, pág. 1092, muy recientemente en NavarRo-Valls, R. Y Martinez TORRÓN, J.: Las objeciones de conciencia en el Derecho español y comparado, McGraw-Hill, Madrid, 1997, pág. 14. 
no meramente psicológicas-, de contenido primordialmente religioso o ideológico", ya tenga por objeto la elección menos lesiva para la propia conciencia entre las alternativas previstas en la norma, eludir el comportamiento contenido en el imperativo legal o la sanción prevista por su incumplimiento $o$, aceptando el mecanismo represivo, lograr la alteración de la ley contraria al personal imperativo ético"; mientras que I.C. IBÁN, L. PRIETO SANCHÍS y A. MOTILLA ${ }^{21}$ la definen como «el incumplimiento de una obligación legal y de naturaleza personal cuya realización produciría en el individuo una lesión grave de la propia conciencia o de las creencias profesadas". G. CÁMARA VILLAR estima que la objeción de conciencia es «un rechazo de la obligación impuesta por la norma jurídica fundamentado en la intimidad de la conciencia individual» 22 y J. OLIVER ARAUJO la define como "la negativa a cumplir un mandato de la autoridad o una norma jurídica, invocando la existencia, en el fuero de la conciencia, de un imperativo que prohibe dicho cumplimiento» ${ }^{23}$. Todavía, D. LLAMAZARES ${ }^{24}$ define la objeción de conciencia como "la negativa individual a prestar obediencia a una norma jurídica por ser contradictoria con la propia conciencia»; J. MARTÍNEZ TORRÓN ${ }^{25}$, como la «negativa del individuo, por motivos de conciencia, a someterse a una conducta que, en principio, resulta jurídicamente exigible» y R. PALOMINO como “el comportamiento individual, basado en los motivos de conciencia y contrario a la norma jurídica estatal» ${ }^{26}$.

Como se desprende de la opiniones transcritas, parece ampliamente aceptado que la objeción de conciencia consiste básicamente en manifestar la incompatibilidad entre los dictados de la conciencia individual y determinadas normas del Ordenamiento jurídico al que la persona se encuentra sujeta. Elementos necesarios, pues, para la conceptualización jurídica de la objeción de conciencia son:

\footnotetext{
21 Ibán, I.C.; Prieto Sanchis, L., Motilla, A.: Curso de Derecho Eclesiástico del Estado, 2." ed., Madrid, 1991, pág. 344.

22. CÁmARA VILLAR, G.: La objeción de conciencia al servicio militar (Las dimensiones constitucionales del problema), Cívitas, Madrid, 1991, pág. 28. pág. 29.

23 Oliver Araujo, J.: La objeción de conciencia al servicio militar, Cívitas, Madrid, 1993,

24 Llamazares, D.: Derecho Eclesiástico del Estado. Derecho de la libertad de conciencia, Madrid, 1991, pág. 705.

25 MARTínez Torrón, J.: «Las objeciones de conciencia y los intereses generales del ordenamiento", en Revista de la Facultad de Derecho de la Universidad Complutense de Madrid, núm. 79 (1992), pág. 200.

${ }^{26}$ Palomino, R.: Las objeciones de conciencia, Ed. Montecorvo, Madrid, 1994., pág.
} 
1) La existencia de una norma jurídica, con un contenido que pueda afectar a las creencias religiosas o morales de los individuos ${ }^{27}$, cuyo cumplimiento no puede obviarse sin incurrir en sanción.

2) La existencia igualmente de un dictado inequívoco de la conciencia individual opuesto al mandato jurídico. "La conciencia es un atributo exclusivo de la persona individual, que además afecta de manera sustancial a la propia personalidad», por ello sólo «puede hablarse de conciencia en presencia de una cierta madurez psicológica» ${ }^{28}$.

3) La ausencia en el Ordenamiento jurídico de normas que permitan diluir el conflicto entre la norma y la conciencia individual.

4) La manifestación del propio sujeto sobre el conflicto surgido entre la norma y su conciencia, sin que sea relevante la mera presunción sobre la existencia de conflicto y, en consecuencia, son inválidas también las manifestaciones que al respecto realicen terceras personas aun siendo cercanas al sujeto.

\section{STATUS CONSTITUCIONAL DE LA OBJECIÓN DE CONCIENCIA AL SERVICIO MILITAR Y EL DE LAS OTRAS OBJECIONES DE CONCIENCIA}

Como es sobradamente conocido, la Constitución española sólo ha regulado expresamente un tipo de objeción de conciencia ${ }^{29}$, cronológicamente quizá el primero y al que mayor número de ciudadanos afecta por el momento, nos referimos a la objeción de conciencia al servicio militar, reconocida en el artículo 30.2 de la Constitución, precepto éste que inicia la Sección 2. ${ }^{a}$-De los derechos y deberes de los ciudadanos-del Capítulo II, del Título I de la Constitución. La Constitución al reconocer exclusivamente la objeción de conciencia al servicio militar y omitir, con poca fortuna, la regulación de

${ }^{27}$ Estimamos necesario que el contenido de la norma jurídica sea tal que pueda resultar incompatible con las convicciones morales o religiosas de los individuos y no meramente contrarias a opiniones o intereses personales de éstos. En este sentido, EscoBAR RocA, G.: La objeción de conciencia en la Constitución Española, ob. cit., pág. 47.

$28 \quad$ lbidem, págs- 51 y 52.

29 Un análisis de la naturaleza jurídica de la objeción de conciencia en: DE LA HERA, A.: "Sobre la naturaleza jurídica de la objeción de conciencia», en IVAN C. IBÁN (Coord.): Libertad y Derecho Fundamental de Libertad Religiosa, Edersa, Madrid, 1989 págs. 141-164. 
cualquier otro tipo, ha propiciado la solución jurídica de ese específico problema, cosa que no ha sucedido con las otras objeciones de conciencia ${ }^{30}$. En el Derecho comparado la objeción de conciencia se ha incorporado a la Constitución en ciertos países y, en otros, ha sido regulada por ley ${ }^{31}$; por otra parte, El Convenio de Roma, en el ámbito internacional, no contempla la objeción de conciencia aunque se reconoce a los Estados nacionales un margen de discrecionalidad para que actúen en lo referente a la misma.

\section{II.1. La objeción de conciencia ¿derecho o exención de un deber?}

La omisión de referencias constitucionales expresas a otros tipos de objeción de conciencia distintos de la que se refiere al servicio militar no debe llevarnos a concluir que su incorporación al Ordenamiento jurídico español está vedada ni tampoco a presumir que tal ausencia deba determinar en todos los supuestos su infraprotección constitucional.

De conformidad con lo que establece el artículo 53.1 CE, los derechos y libertades del Capítulo II del Título I (arts. 14 a 38) sólo podrán desarrollarse mediante ley que, en todo caso deberá, afirma la Constitución, respetar su contenido esencial, dicho contenido básico permite conocer qué conductas quedan amparadas por el ámbito de cada derecho ${ }^{32}$. Así, una determinada conducta individual, aún no reconocida expresamente en la Constitución como derecho autónomo, puede estar comprendida dentro del contenido propio de un derecho constitucional, tenga o no, en razón a sus garantías, el carácter de derecho fundamental ${ }^{33}$. Por otro lado, puede hablarse también de la existencia de derechos con fundamen-

30 Actualmente se consideran casos de objeción de conciencia, entre otros, la oposición a realizar abortos, a sufragar impuestos en ciertos casos, a participar en la institución del Jurado, a prestar juramento y a recibir ciertos tratamientos médicos. Sobre este último aspecto tratamos específicamente en estas páginas.

31 La Constitución alemana, reconoce la objeción de conciencia al servicio militar junto a las libertad de creencias, de conciencia y religiosa (art. 4.3.) y, vuelve a tratar de dicha objeción de conciencia al referirse a la prestación del servicio militar (el art. 12 a. 1,), también reciben tratamiento constitucional en Austria, Chipre, Holanda, Malta o Portugal. Su tratamiento legislativo lo encontramos en Bélgica, Grecia, Italia o Suecia.

32 El problema de la determinación del contenido esencial de un derecho es tema sumamente complejo al que el Tribunal Constitucional ha aludido reiteradamente en su jurisprudencia. No podemos, en estas breves páginas, adentrarnos en este aspecto.

33 STC 53/85, de 11 de abril. 
to constitucional, es decir, derechos que aún no estando expresamente reconocidos en el texto constitucional encuentran en otro derecho sí contemplado en la Constitución la base de su existencia y de su reconocimiento legal.

Que una conducta concreta pueda ser definida como parte del contenido esencial de un determinado derecho o, por el contrario, como un correlato de aquél se deducirá de la interpretación constitucional y, en todo caso, determinará el nivel de protección constitucional que dicha conducta pueda recibir ${ }^{34}$. En el primer caso, al ser el aspecto concreto parte del contenido esencial del derecho, recibe las garantías que éste tenga asignadas; en el segundo caso, si se trata de un derecho con fundamento constitucional, el margen de discrecionalidad del legislador ordinario aumenta permitiendo diversas opciones en función, por lo general, de planteamientos políticos e, igualmente, puede ser diverso su nivel de garantías.

El régimen constitucional español permitiría, en mi opinión, la incorporación de alguno de los tipos de objeción de conciencia que actualmente se defienden como tales. Pero, como ya se ha afirmado, no todos podrían recibir el mismo status jurídico, pues cada uno debería ser interpretado en relación con los demás bienes jurídicos protegidos por el Ordenamiento.

Con todo, debe aceptarse que los Ordenamientos jurídicos no se encuentran preparados para aceptar la amplísima variedad de tipos de objeción de conciencia que teóricamente podrían presentarse, así «las legislaciones - nacionales y extranjeras - o no la admiten en ningún supuesto 0 sólo en algunas materias concretas. Esta ausencia de reconocimiento o, en el mejor de los casos, reconocimiento restrictivo tiene su causa en el temor o desconfianza del legislador ante las consecuencias que se derivarían de una aceptación amplia de la objeción de conciencia, pues, podría poner en jaque la propia existencia del derecho y del Estado" ${ }^{35}$.

El artículo 30.2 de la Constitución, tras declarar que la ley fijará las obligaciones militares de los españoles, establece que, también por ley,

${ }^{34}$ El Defensor del Pueblo, en el recurso de inconstitucionalidad que resolvió la STC 160/1987, de 27 de octubre, defendía que la objeción de conciencia constituía per se o por derivación del artículo 16 (libertad ideológica) un verdadero derecho fundamental. Esta afirmación no fue aceptada por el Tribunal Constitucional (JF 3) que, correctamente a mi juicio, distingue entre el supuesto en el que un aspecto forme parte del contenido esencial de un derecho y aquel otro caso en el que a dicho aspecto pueda encontrarse un fundamento constitucional para su reconocimiento jurídico.

35 Oliver Araujo, J.: La objeción de conciencia al servicio militar, ob. cit., pág. 33. 
se regulará con las debidas garantías, la objeción de conciencia ${ }^{36}$, enclavándola como una más de las causas de exención del servicio militar obligatorio.

El Tribunal Constitucional, en su STC 160/1987, de 27 de octubre (FJ $3)$, apoyándose en una resolución anterior ${ }^{37}$, en la que establece que los derechos fundamentales reservados a la ley orgánica son los comprendidos en la Sección 1.a , del Capítulo II, del Título I (arts. 15 a 29 CE), concluye que la objeción de conciencia al servicio militar no es un derecho fundamental (aunque la Constitución le otorgue la protección específica del recurso de amparo), lo cual permitió considerar acorde con la Constitución el desarrollo por ley ordinaria del artículo 30.2 en este punto.

Por ello, no se ha reconocido un derecho a ser objetor sino un derecho a ser declarado objetor siempre que se cumplan los requisitos establecidos en la Ley a la que la Constitución se remite. No estamos, pues, ante un derecho de la persona sino ante una causa de la exención del servicio militar ${ }^{38}$. Estima el Tribunal, por otro lado, que de no haberse regulado expresamente la objeción de conciencia al servicio militar en el citado artículo 30.2 de la Constitución, su indiscutible relación con la libertad ideológica del artículo 16.1 no habría bastado para exceptuar el cumplimiento de un deber constitucional expreso: la defensa de España ${ }^{39}$.

Quizá deba insistirse en que el Tribunal Constitucional considera especialmente relevante para resolver el recurso de inconstitucionalidad sobre la objeción de conciencia al servicio militar que ésta haya sido regulada como excepción a un deber constitucional expreso (defender a España) y aunque no niega el Tribunal su posible relación con las libertades contenidas en el artículo 16.1 CE, estima que ello "no autoriza ni permite calificarlo de fundamental». A ello obsta - dice el Tribunal— la consideración de que su

36 El artículo 30.2 de la Constitución establece: «La ley fijará las obligaciones militares de los españoles y regulará, con las debidas garantías, la objeción de conciencia, así como las demás causas de exención del servicio militar obligatorio, pudiendo imponer, en su caso, una prestación social sustitutoria."

37 STC 76/1983, de 5 de agosto.

38 Afirma el Tribunal Constitucional al respecto (STC 160/1987, de 27 de octubre), basándose en su STC 15/1982 (FJ 7) que «a diferencia de lo que ocurre con otras manifestaciones de libertad de conciencia, el derecho a la objeción no consiste fundamentalmente en la garantía jurídica de la abstención de una determinada conducta (la del servicio militar), sino que ese derecho introduce una excepción que ha de ser declarada efectivamente existente en cada caso. Es decir, que no se garantiza una abstención, sino el derecho a ser declarado exento el objetor del servicio militar, que habrá de cumplirse de no mediar esa declaración" (FJ 4).

39 STC 160/1987, de 27 de octubre (FJ 3). 
núcleo o contenido esencial ... consiste en constituir un derecho a ser declarado exento del deber general de prestar el servicio militar ... sustituyéndolo, en su caso, por una prestación social sustitutoria» (FJ 3) ${ }^{40}$. No hay, pues, reconocimiento de un ámbito de libertad dentro del cual el sujeto actúa sin interferencias del poder público y, por ello, el Tribunal Constitucional puede declarar acorde con la Constitución que el objetor deba declarar expresamente los aspectos religiosos o de conciencia que entran en conflicto con la norma general sin que ello vulnere las libertades constitucionalizadas en el artículo 16.1 .

Conforme a lo expuesto, si bien parece que la constitucionalización expresa, en los términos vistos, de la objeción de conciencia al servicio militar perjudica sustancialmente su consideración como derecho fundamental, es también cierto que la omisión de dicha regulación habría impedido - a juicio del Tribunal Constitucional- su consideración como parte del contenido esencial de las libertades reconocidas en el reiterado artículo 16.1 de la Constitución.

Son, pues, aspectos esenciales de la resolución del Tribunal Constitucional en este caso ${ }^{41}$ : a) la existencia de un deber constitucional expreso; b) la regulación concreta de la objeción de conciencia como una más de las causas de exención de dicho deber.

Hasta aquí, la posición del Tribunal Constitucional acerca de la única objeción de conciencia expresamente regulada en nuestro Texto Fundamental. En este mismo orden de cosas, podría estimarse que esta posición del Tribunal Constitucional en relación con la objeción de conciencia podría resultar contradictoria respecto de pronunciamientos anteriores en los que la objeción de conciencia se vinculaba o incluia en el contenido de las libertades del artículo 16.1 CE, concretamente en las SSTC 15/82, de 23 de abril y 53/85, de 11 de abril. Estimo, sin embargo, que el contenido de dichas sentencias permite una interpretación conciliadora.

Por un lado, la STC 15/1982, de 23 de abril (anterior al desarrollo legislativo del artículo $30.2 \mathrm{CE}$ ), declaró que el objetor de conciencia tenía derecho a que su incorporación a filas se aplazara hasta que se configurase el procedimiento que pudiera conferir plena realización a su derecho de objetor

40. STC 160/1987, de 27 de octubre (FJ 3). Igual argumentación, en este punto, se contenía ya en la STC 15/1982, de 23 de abril (FJ 7).

41 Igual argumentación se encuentra en la resolución de diversas cuestiones de inconstitucionalidad (STC 161/1987, de 27 de octubre). 
(FJ 8). Si bien en esta resolución el Tribunal Constitucional afirma que «la libertad de conciencia es una concreción de la libertad ideológica, que nuestra Constitución reconoce en el artículo 16, puede afirmarse que la objeción de conciencia es un derecho explícita e implícitamente reconocido en el ordenamiento constitucional español» ( FJ 6), es también cierto que tal manifestación se hace para añadir que, como reiteradamente ha dicho el Tribunal, la Constitución es directamente aplicable en todos sus puntos y que no es la ley de desarrollo la que hace surgir el derecho sino la que permite su plena aplicabilidad y eficacia ${ }^{42}$.

Por otro lado, el Tribunal Constitucional ya manifiesta en esta temprana resolución lo que después fundamentará sus Resoluciones 160 y 161 de 1987, a saber, que la objeción de conciencia al servicio militar es una exención de un deber constitucional ${ }^{43}$, con lo cual no hay quiebra de la doctrina del Tribunal en este punto.

Con respecto a la segunda de las sentencias citadas, la 53/1985, de 11 de abril, que resolvió el recurso de inconstitucionalidad interpuesto contra la legislación que despenalizaba ciertos supuestos de aborto, el Tribunal Constitucional afirmaba en relación con la posible objeción de conciencia de los médicos (en un obiter dictum, pues era tema ajeno al enjuiciamiento de la constitucionalidad de la norma impugnada), que la «objeción de conciencia forma parte del contenido del derecho fundamental a la libertad ideológica y religiosa reconocido en el artículo 16.1 de la Constitución y, como ha indicado este Tribunal en diversas ocasiones, la Constitución es directamente aplicable, especialmente en materia de derechos fundamentales» (FJ 14).

La manifestación del Tribunal, en el contexto en el que es formulada en la Sentencia 53/1985, es coherente con la tesis que venimos defendiendo, que no es otra sino la de que el Ordenamiento constitucional español no ha contemplado una única opción en cuanto al reconocimiento y regulación del fenómeno de la objeción de conciencia. La objeción de conciencia de los

42 Las manifestaciones del Tribunal en este sentido sirven para negar la tesis del Abogado del Estado que aducía, para denegar la solicitud del recurrente, que el derecho a la objeción de conciencia al servicio militar sólo podría ser recurrida en amparo cuando fuera desarrollada por la ley a la que aludía el artículo 30.2 de la Constitución.

43 El Tribunal Constitucional afirma: «... a diferencia de lo que ocurre con otras manifestaciones de la libertad de conciencia, el derecho a la objeción de conciencia no consiste fundamentalmente en la garantía jurídica de la abstención de una determinada conducta - la del servicio militar en este caso-, pues la objeción de conciencia entraña una excepcional exención a un deber —el deber de defender a España - que se impone con carácter general en el artículo 30.1 de la Constitución y que con ese mismo carácter debe ser exigido por los poderes públicos.» (FJ 7). 
médicos oponiéndose a realizar abortos no pugna con ninguna otra norma constitucional que establezca el deber de realizar este tipo de operaciones, no puede, pues, configurarse como exención de un deber constitucional inexistente. Siendo así, este tipo concreto de objeción de conciencia puede ser considerada, como asi lo afirma el Tribunal, parte del contenido de las libertades consagradas en el artículo 16.1 del Texto constitucional. Por su contenido, además, este tipo de objeción de conciencia reúne los requisitos esenciales de la definición básica de la misma, puesto que la interrupción del proceso de gestación humana es asunto relevante sobre el que la conciencia individual puede mantener una postura propia y, por otro lado, no existe un deber jurídico de colaboración o participación en estas prácticas. Este tipo de objeción de conciencia forma parte, pues, de la esfera de libertad religiosa e ideológica tutelada en el precepto citado y recibe, como parte de ellas, las máximas garantías que el Ordenamiento otorga.

Las sentencias citadas, de aceptarse la tesis que mantengo, no sólo no son contradictorias, sino que confirman que la objeción de conciencia ni es un derecho público subjetivo de carácter general, lo cual, como el mismo Tribunal afirma, sería contrario a la idea de Estado ${ }^{44}$, ni tiene necesariamente que quedar reducida al tipo que se constitucionaliza en el artículo 30.2 de la Constitución. Las manifestaciones de la conciencia individual podrán ser o no tomadas jurídicamente en consideración en función de los demás derechos, libertades y bienes constitucionalmente protegidos que se vean afectados en cada caso y, especialmente, en función de que exista o no un deber constitucional contrario a la pretensión del objetor.

A modo de conclusión sobre este punto podríamos afirmar que en nuestro Ordenamiento constitucional no puede darse una respuesta única al problema de la objeción de conciencia, la cual puede encontrar apoyo, al menos, en los siguientes status jurídicos:

a) La objeción de conciencia como parte del contenido esencial de las libertades reconocidas en el artículo 16.1 de la Constitución, para lo cual

44 El Tribunal Constitucional contestaba negativamente a la posibilidad de que exista un derecho general a la objeción de conciencia en los siguientes términos: “... el derecho a ser eximido del cumplimiento de los deberes constitucionales o legales por resultar ese cumplimiento contrario a las propias convicciones, no está reconocido ni cabe imaginar que lo estuviera en nuestro Derecho o en Derecho alguno, pues significaría la negación misma de la idea de Estado. Lo que puede ocurrir es que se admita excepcionalmente respecto de un deber concreto" (STC 160/1982, de 27 de octubre). 
es preciso que, además de sus elementos esenciales ${ }^{45}$ (en especial, que esté en peligro las convicciones morales o religiosas del individuo), la objeción de conciencia no choque con un deber constitucional de carácter general (es el caso de la objeción de conciencia de los médicos a realizar abortos). En ausencia de un deber de esta naturaleza, los poderes públicos no pueden obligar a los ciudadanos a prestaciones que violenten sus conciencias, por lo que resulta necesario aceptar la objeción de aquellos que manifiesten expresamente tal conflicto ${ }^{46}$. Estimo, además, que este tipo de objeción de conciencia, al configurarse como esfera de libertad del sujeto, no exige de éste el cumplimiento de requisitos especiales distintos de la manifestación de su objeción.

b) La objeción de conciencia como una exención de obligaciones constitucionales. Este es el caso de la objeción de conciencia al servicio militar que, aunque pueda encontrar su fundamento último en la libertad de conciencia, ha sido el Ordenamiento positivo el que, al establecer el deber de defender a España, ha condicionado inexcusablemente su reconocimiento como exención de tal deber y no como una esfera de libertad individual.

c) Todavía cabe un tercer supuesto, cuando el deber jurídicamente establecido no posea rango constitucional ${ }^{47}$. En estos casos, sólo la necesaria ponderación entre las libertad fundamentales del artículo 16.1 de la Constitución en la que la objeción se apoye y aquel otro precepto constitucional en el que tal deber jurídico se fundamente, permitirá adoptar una solución acorde con los principios constitucionales

d) Por último, si la Constitución no incorpora expresamente la posibilidad de objetar ante un deber constitucional concreto, su incorporación legal al Ordenamiento es difícil ya que habría que fundamentar dicha excepción. Este sería el caso de la objeción de conciencia fiscal, cuya viabilidad constitucional es realmente dudosa ya que une a su escasa relación con las

45 Escobar Roca, G.: La objeción de conciencia en la Constitución Española, ob. cit., pág. 53.

46 A pesar de la regulación adoptada en la reciente Ley sobre el Jurado, el artículo 125 de la Constitución establece con toda claridad que la participación de los ciudadanos en la Administración de Justicia, mediante la acción popular y la institución del Jurado, es una facultad y no un deber. Creo, por ello, que las demandas en favor del reconocimiento de la objeción de conciencia a ser miembro de un Jurado deberán prosperar y que si tal problema llegara a someterse al Tribunal Constitucional éste no podría obviar la redacción constitucional que establece que los "ciudadanos podrán ejercer ...." y no que deberán ejercer ...

47 Así sucede con la actual regulación de la institución del jurado, en la que la ley establece la obligación de los ciudadanos de participar como jurados cuando sean llamados para ello. 
convicciones morales la pugna con la obligación general de contribuir al sostenimiento de los gastos públicos de acuerdo con la respectiva capacidad económica establecida en el artículo 31.1 de la Constitución.

Según lo expuesto, estimamos que en nuestro Ordenamiento la objeción de conciencia no puede recibir una idéntica regulación puesto que los diversos tipos de objeción de conciencia no poseen un único status constitucional. Así, la regulación de cada una de sus manifestaciones, cuando ello sea posible, estará en función del específico aspecto de que se trate y de la posición constitucional que el mismo tenga en el Ordenamiento ${ }^{48}$. Estos apuntes conceptuales nos servirán, tras señalar cuál es el sujeto de la objeción de conciencia, para reflexionar sobre uno de los aspectos últimamente más debatidos: la objeción de conciencia a ciertos tratamientos médicos.

\section{II.2. El sujeto de la objeción de conciencia}

Sentada nuestra opinión acerca de la imposibilidad de que nuestro Ordenamiento español ofrezca una solución única a la multiplicidad de tipos de objeción de conciencia que ya actualmente han aparecido, si debemos, aunque sea con brevedad, señalar que, en todo caso, nos encontramos ante una posibilidad únicamente ejercitable por la persona física individual.

Aun sin olvidar la dicotomía tradicional entre capacidad jurídica y capacidad de obrar ${ }^{49}$, considero preferible, en materia de derechos y libertades, distinguir entre titularidad, ejercicio efectivo y defensa procesal ${ }^{50}$. En ocasiones el sujeto goza de las tres situaciones aunque no siempre es así y debe acudirse a la naturaleza de cada uno de los derechos $y$, también, a las circunstancias del sujeto (mayor o menor de edad, capaz o incapaz, persona física o jurídica ...) para determinar el verdadero alcance de estas tres situaciones en el caso concreto.

48 Sobre el argumento de la no redundancia, sobre la teoría de los derechos concurrentes y posición del autor, ver: Escobar RocA, G.: La objeción de conciencia en la Constitución Española, ob. cit., pág. 205.

49 En favor de la superación de esta distinción: Escobar RocA, G.: La objeción de conciencia en la Constitución Española, ob. cit., pág. 238.

5o SANChez FerRiz, R.: Estudio sobre las libertades, 2.9 ed., Tirant lo Blanch, Valencia, 1995, pág. 160. Torres del Moral, A.: Principios de Derecho Constitucional Español, Vol. I, Servicio de Publicaciones de la Facultad de Derecho, Universidad Complutense, Madrid, 1992, pág. 346. 
La Constitución ha incorporado tanto derechos de titularidad individual como otros de carácter colectivo y, algunos en fin, que pueden ser tanto ejercidos por las personas físicas como jurídicas. La naturaleza de cada derecho o libertad nos mostrará, como hemos señalado, el sujeto del mismo (así, el sujeto individual es indiscutible, entre otros, en el derecho de sufragio, en el derecho a la libertad personal, en el derecho al matrimonio; mientras que se considera de carácter grupal, por ejemplo, el derecho de huelga). El propio artículo $16.1 \mathrm{CE}$, recoge derechos ejercitables por el sujeto individual -la libertad religiosa e ideológica- a la vez que reconoce otros cuyo sujeto puede ser tanto individual como colectivo o comunitario - libertad de culto- ${ }^{51}$.

En el caso concreto de la libertad religiosa, la Constitución contempla un supuesto peculiar en el que se separa la titularidad del ejercicio ${ }^{52}$ al disponer, el artículo 27.3, que los padres tiene derecho a que sus hijos reciban la formación religiosa acorde con las convicciones de aquéllos. Sobre este punto volveremos en apartados siguientes.

Como señalamos al principio de estas páginas, cualquiera que sea la definición de objeción de conciencia por la que nos decantemos, en ella se manifiesta la oposición de la conciencia individual a una obligación jurídica (constitucional o legalmente establecida). Este carácter individual es lo que, a juicio de un sector doctrinal, distingue la objeción de conciencia de otras situaciones como la de la desobediencia civil, pues mientras éste movimiento intenta una transformación del Ordenamiento jurídico, el objetor plantea un conflicto personal, privado y persigue objetivos igualmente individuales: "resolver la íntima antinomia de la conciencia y la existencia personal con lo prescrito por la regla de la mayoría» 53 .

El objetor no persigue fines colectivos ni transformar con su actitud el Ordenamiento jurídico (aunque indirectamente la objeción generalizada a una norma pueda provocar un cambio legislativo); no es preciso tampoco que la norma sea considerada injusta por el objetor, basta con que provoque un conflicto real con los dictados de la propia conciencia. De todo ello se concluye que sólo el individuo puede ser el sujeto de un supuesto de objeción de conciencia.

51 Estegan, J. de; GonzÁlez Trevijano, P.J.: Curso de Derecho Constitucional Español, Vol. II, ob. cit., pág. 48. TORRES DEL MORAL, A.: las cataloga como libertades públicas, en Principios de Derecho Constitucional Español, Vol. I, ob. cit., pág. 353.

52 Torres del Moral, A.: Principios de Derecho Constitucional Español, ob. cit., vol. I, pág. 346.

53 CÁmARA VILLAR, G.: La objeción de conciencia al servicio militar (Las dimensiones constitucionales del problema), ob. cit., pág. 23. En igual sentido, Escobar RocA, G.: La objeción de conciencia en la Constitución Española, ob. cit., pág. 55. 
Pero, además, la naturaleza de ésta exige que sea un sujeto capaz para que su manifestación sea jurídicamente relevante ${ }^{54}$. El problema de la titularidad es también, como se ha afirmado acertadamente, un problema de límites a los derechos. En este sentido, como afirma G. ESCOBAR ROCA, en ocasiones el sujeto está realmente fuera del supuesto de hecho (límites impropios) 0 , por razón de circunstancias concretas, tal derecho puede modularse 0 , incluso, restringirse legítimamente (límites directos) ${ }^{55}$. Conforme a esta opinión y respecto al tema que aquí abordamos, se está fuera del concepto de objeción de conciencia (límites impropios), "cuando el presunto titular no sea destinatario de ningún deber jurídico, cuando carezca de la madurez necesaria para poseer conciencia moral o cuando en el caso concreto no estemos en presencia de un auténtico conflicto de conciencia» ${ }^{56}$. Volveremos sobre estos extremos al analizar la posible objeción de conciencia en menores de edad o personas incapaces.

Por otro lado, señalaremos que la libertad religiosa y la libertad ideológica garantizadas en el artículo 16.1 de la Constitución no pueden circunscribirse a los nacionales, sino que coincidimos con otros autores en que su titularidad corresponde tanto a éstos como a los extranjeros ${ }^{57}$. Restringir la titularidad de estas libertades precisamente a los extranjeros carece se sentido ya que la diversidad religiosa o cultural es uno de los elementos que distinguen a los diversos pueblos; el Tribunal Constitucional ha confirmado esta opinión, señalando que la libertad ideológica forma parte de un grupo de derechos que "pertenecen a la persona en cuanto tal y no como ciudadano ... que son imprescindibles para la garantía de la dignidad humana, que, constituye fundamento del orden político español. Derechos tales como el derecho a la vida, a la integridad física y moral, a la intimidad, la libertad ideológica, etc., corresponden a los extranjeros por propio mandato constitucional, y no resulta posible un tratamiento desigual respecto a ellos en relación con los españoles» ${ }^{58}$.

54 En el ATSJ de Madrid, de 23 de diciembre de 1992, se afirmaba: "Si la paciente es mayor de edad, y adopta su decisión libremente, si no se trata de un menor, ni de un incapacitado, el Juez no tiene obligación ineludible de conceder autorización para realizar transfusiones ...”. Citado en Navarro Valis, R., Martinez TorRón, J.: Las objeciones de conciencia en el Derecho español y comparado, ob. cit, pág. 143. La alusión a los menores resultan más acertadas y concretas que la exigencia de "cierta madurez psicológica" a la que se refiere G. EsCOBAR RocA, en La objeción de conciencia en la Constitución Española, ob. cit., pág. 52.

55 Escobar Roca, G.: La objeción de conciencia en la Constitución Española, ob. cit., pág. 238.

$56 \mathrm{Ibidem}$.

57 lbidem.

58 STC 107/1984, de 23 de noviembre (FJ 3). 
Por último, por lo afirmado hasta aquí, no consideramos sujetos válidos de la objeción de conciencia a las personas jurídicas. Tal afirmación se deduce de las características esenciales de la objeción de conciencia que antes señalamos, toda vez que resulta imposible que se produzca en las personas jurídicas la oposición entre un deber jurídico y la conciencia individual. Ello, sin embargo, no impide otros tipos de oposición de las personas jurídicas ante determinadas prescripciones del ordenamiento jurídico pero tales manifestaciones serán producto de la libertad de expresión que sí les asiste o bien mandatos o sugerencias a aquellas personas que se encuentren dentro de su ámbito de influencia (tal es el caso de las distintas confesiones religiosas o de los grupos ideológicos). Ciertamente produciria cierto recelo, como afirma $\mathrm{G}$. ESCOBAR ROCA ${ }^{59}$, que las personas jurídicas pudieran ejercer una suerte de derecho de objeción respecto de situaciones individuales con el consiguiente peligro de limitar o anular incluso la conciencia individual. Nos parece, pues, correcta la negativa del Tribunal Constitucional a admitir ni siquiera como coadyuvante a una confesión religiosa (Unión de Iglesias Cristianas Adventistas del Séptimo Día) en un caso de objeción de conciencia ${ }^{60}$.

\section{OBJECIÓN DE CONCIENCIA Y TRATAMIENTOS MÉDICOS INDIVIDUALES EN EL ORDENAMIENTO CONSTITUCIONAL}

\section{III.1. Objeción de conciencia a tratamientos médicos: tipos ${ }^{61}$}

Es este uno de los aspectos que ya vienen considerándose clásicos en cuanto a la objeción de conciencia, surgidos, principalmente, en casos en los que se veían implicados los miembros del grupo religioso Testigos de Jehová ${ }^{62}$, que se oponen a recibir transfusiones de sangre de conformidad

59 Escobar Roca, G.: La objeción de conciencia en la Constitución Española, ob. cit., pág. 238.

60 ATC 578/1984.

61 Un estudio exhaustivo en: Navarro-Valls, R., Martínez Torrón, J., Jusdado, M.A.: «La objeción de conciencia a tratamientos médicos: Derecho comparado y Derecho español", en "Las relaciones entre la Iglesia y el Estado (Estudios en memoria del Profesor Pedro Lombardía), Universidad Complutense/Universidad de Navarra/Edersa, Madrid, 1989.

62 Este movimiento religioso se ha extendido desde su inicial aparición en Norteamérica durante el siglo pasado por diversos países europeos. Cfr. NAVARRo-VALLS, R.: “Las objeciones de conciencia", en FerRez Ortíz, J. (Coord.): Derecho Eclesiástico del Estado Español, 4." ed., Eunsa, Pamplona, 1996, pág. 209. 
con lo que consideran es un mandato divino reflejado en ciertos textos de la Biblia. La recepción de sangre, ya sea propia o ajena, representa para los miembros de los Testigos de Jehová la condenación eterna aunque, en determinados casos, esta negativa represente un claro peligro para su vida. Como ha señalado acertadamente la doctrina, estos supuestos deben diferenciarse de aquellos otros casos en los que los objetores se oponen a recibir cualquier intervención médica al defender "que cualquier dolencia puede sanar exclusivamente mediante la oración, y consideran ilícito el recurso a los tratamientos médicos de manera generalizada. Únicamente algunos aceptan recibir analgésicos para mitigar el dolor» 63 .

En el análisis de la denominada objeción de conciencia a los tratamientos médicos suelen distinguirse los distintos supuestos en razón, por un lado, de la edad y la capacidad del sujeto y, por otro, por la implicación individual o social de la objeción. Así, tendríamos:

1. Por la edad y capacidad del sujeto:

a) El caso de un adulto capaz.

b) El de un adulto incapaz.

c) $\mathrm{Y}$ el de un menor de edad ${ }^{64}$.

2. Por la implicación individual o social:

a) La objeción que sólo afecta a la salud o a la vida del sujeto.

b) La objeción que afecta o puede afectar a la salud o a la vida de un sector de población.

Veamos los distintos supuestos en orden a los principios constitucionales a los que antes hemos aludido.

\section{III.2. Tratamientos médicos en persona adulta y capaz}

Por centrarnos en el ámbito constitucional español al que se refieren estas reflexiones, la denominada objeción de conciencia a tratamientos

63 Este es el caso del movimiento Christian Science, fundado por Mery Baker Eddy (Boston, 1879), Cfr. Navarro-Valls, R.: «Las objeciones de conciencia», en Ferrer Ortiz, J. (Coord.): Derecho Eclesiástico del Estado Español, ob. cit., pág. 209.

64 Palomino, R.: Las objeciones de conciencia, ob. cit., pág. 255. 
médicos en personas adultas y plenamente capaces, cuando dicho tratamiento sólo afecta a la vida del sujeto, son de difícil encuadre constitucional, puesto que, siguiendo lo ya expuesto, en todo caso la objeción de conciencia debe oponer la voluntad individual a una norma o mandato expreso cosa que no ocurre en este supuesto. No existe entre los deberes constitucionales el de someterse a ningún tratamiento médico concreto puesto que no existe tampoco la obligación de vivir ni de conservar la vida ${ }^{65}$.

El derecho a la vida, reconocido en el artículo 15 de la Constitución, representa, como tiene afirmado el Tribunal Constitucional, el «derecho fundamental esencial y troncal en cuanto es el supuesto ontológico sin el que los restantes derechos no tendrian existencia posible" ${ }^{66}$, los derechos fundamentales en su conjunto, afirma igualmente el Tribunal, son los componentes estructurales básicos del orden jurídico y expresan el sistema de valores adoptado por el régimen constitucional y son, finalmente y como establece el artículo 10 de la Constitución, el cfundamento del orden político y de la paz social», de donde se deduce no sólo la obligación negativa del Estado de no lesionar la esfera individual o institucional protegida por los derechos fundamentales, sino también la obligación positiva de contribuir a la efectividad de tales derechos y de los valores que representan, aun cuando no exista una pretensión subjetiva por parte de los ciudadanos" "67. Así, pues, la inicial abstención del Estado puede extenderse a una acción positiva de tutela de la vida de los ciudadanos pero no es tan claro en el Ordenamiento español que tal tutela pueda imponerse contra la voluntad del sujeto ${ }^{68}$. Falta, pues, en estos casos el presupuesto principal: la oposición entre una norma imperativa y el dictado de la conciencia, de donde se deduce que no nos encontramos ante un caso de objeción de conciencia sino ante un supuesto de ejercicio de la libertad no restringido por el Ordenamiento.

La obligación general de los poderes públicos en favor de la eficacia de los derechos fundamentales no permitiría, a nuestro juicio, desconocer la voluntad de un sujeto capaz que se opusiera a recibir cualquier tipo de tratamiento médico (ya se trate de una transfusión de sangre como de cualquier

65 El artículo 143 del Código Penal tipifica la inducción y la cooperación al suicidio pero no los actos del propio sujeto tendentes a quitarse la vida aun en el caso de que no conseguirlo.

66 STC 53/85, de 11 de abril.

67 STC 53/85, de 11 de abril (FJ 4).

68 El Tribunal Supremo de Estados Unidos, en una resolución de 26 de junio de 1997, declaró contraria a la Constitución la asistencia prestada a enfermos terminales para morir (Caso Kervorkian); el Tribunal considera que la asistencia al suicidio no es una libertades protegida por la Constitución americana.. 
otra terapia) aun en el caso de que tal negativa pusiera su vida en un riesgo cierto y grave. Al no estar los poderes públicos habilitados para imponer una determinada conducta al respecto, la oposición del sujeto a recibir un determinado tratamiento no adquiere naturaleza jurídica de objeción de conciencia sino de pura manifestación de voluntad que, como tal, debe ser admitida y respetada por el personal médico y, en su caso, por la autoridad judicial. En este sentido, la Ley General de Sanidad, establece que el paciente puede negarse a recibir un tratamiento médico concreto, salvo en casos de peligro inminente para su vida o para la salud pública, aunque cuando así to haga deberá solicitar el alta voluntaria, con lo cual se pretende liberar de responsabilidad al hospital y al personal médico que recomendaban la terapia ${ }^{69}$.

Una de las sentencias del Tribunal Constitucional que inciden en este tema es la que resolvió el recurso de amparo presentado por presos, perteneciente a la organización GRAPO, que se mantenían en huelga de hambre contra la alimentación forzosa que la Administración les aplicó. El Tribunal Constitucional declaró acorde a la Constitución tal alimentación forzosa, aunque para ello debió estimar que se daban circunstancia especiales como era la existencia de una especial relación de sujeción del sujeto por razón del régimen penitenciario al que estaba sometido y, aunque no expresamente, de dicha sentencia se desprende que también se tomaron en consideración los fines que perseguían los sujetos que no parecían estar en relación con motivos de conciencia sino que representaban realmente una postura política alejada del problema de la objeción de conciencia. En este sentido, dice el Tribunal Constitucional que, para que "exista violación del artículo 16.1 de la Constitución, es preciso que los actos del poder público perturben o impidan de algún modo la adopción o el mantenimiento en libertad de una determinado ideología o pensamiento". De otra parte, se exige —continúa diciendo el Tribunal— "que entre el contenido y sostenimiento del pensamiento y lo dispuesto en los actos que se combatan quepa apreciar una relación de causalidad suficiente» ${ }^{70}$.

69 Artículo 10.6, 9 y artículo 11.4 de la Ley 14/1986, de 25 de abril, General de Sanidad. Recientemente, los Códigos deontológicos de los profesionales de la medicina recogen la necesidad de respetar las decisiones de los pacientes, incluso las huelgas de hambre.

70 Recordemos que, en la STC 120/1990, de 27 de junio, el Tribunal Constitucional manifiesta que la asistencia médica coactiva, impuesta contra la voluntad de la persona, vulnera el artículo $15 \mathrm{CE}$, salvo que exista justificación constitucional, justificación que, a juicio del Tribunal, se apreciaba en el caso de la alimentación obligatoria a miembros del GRAPO internados en un Centro penitenciario y en huelga de hambre. Estas causas justificativas para la alimentación forzosa radicaban en, por un lado, la defensa de los derechos constitucionales a la vida y a la salud de las personas y, por otro lado, en las obligaciones que la Administración penitenciaría asumía respecto de los individuos internados en Centros Penitenciarios. 
Al negar, como creo correcto, la naturaleza de objeción de conciencia al supuesto de la huelga de hambre de los miembros del GRAPO se logra circunscribir a sus justos términos la naturaleza jurídica de la objeción de conciencia a un conflicto que tenga su raíz en una postura ideológica o religiosa no coyuntural ni de mera oportunidad política como parecía ser el supuesto que citamos. Es urgente, pues, que se extremen los esfuerzos por circunscribir los casos de objeción de conciencia a los que realmente sean tales, ya que su extensión artificial dará al traste con las posibilidades que el Ordenamiento constitucional ofrece para regular los casos que auténticamente respondan a conflictos de conciencia ${ }^{71}$.

Por último, es relevante la afirmación del Tribunal Constitucional en orden a valorar la decisión «de quien asume el riesgo de morir en un acto de voluntad que sólo a él afecta, en cuyo caso podría -afirma el Tribunalsostenerse la ilicitud de la asistencia médica obligatoria ...» ${ }^{72}$, pero, incluso en tal caso, la decisión debe obedecer a un conflicto de conciencia, ya que, en caso contrario, no estariamos en puridad ante un supuesto de objeción de conciencia. Por tanto, el enfermo puede negarse a recibir un determinado tratamiento médico por razones de conciencia pero, siendo mayor de edad capaz, tal manifestación es de igual naturaleza que aquélla otra hecha desde la libre voluntad del sujeto y sin motivaciones religiosas. Defender que sólo por razones religiosas o ideológicas puede el sujeto poner en peligro su vida no es un argumento jurídico válido, pues, conforme a este razonamiento, podríamos llegar a concluir -erróneamente a mi juicio- que todo aquel que no pueda alegar motivos de conciencia queda obligado a recibir la terapia que el personal médico estime pertinente, conflicto, por otro lado, que ya ha resuelto la Ley General de Sanidad en favor de la libertad del paciente ${ }^{73}$.

La opinión favorable a la libertad del sujeto capaz, queda reflejada en el auto del Tribunal Superior de Justicia de Madrid, de 23 de diciembre de 1992, ante la decisión de un órgano jurisdiccional inferior, por la que se autorizaba a dar tratamiento de hemoterapia a una enferma de cancer, miembro de los Testigo de Jehová, al afirmar que si «la paciente es mayor de edad y adopta la

71 Recordemos que el artículo 143 del Código Penal establece penas para todos aquellos que induzcan o cooperen en el suicidio. Castigándose con penas uno o dos grados inferiores dicho auxilio o cooperación al suicidio cuando se produzca en una persona aquejada de una enfermedad incurable y a petición de ésta.

72 STC 120/1990, de 27 de junio, (FJ 7).

73 Artículo 10 de la Ley 14/1986, de 25 de abril, General de Sanidad. 
decisión libremente, si no se trata de un menor, ni un incapacitado,el Juez no tiene obligación ineludible de conceder autorización para realizar transfusiones, que entrañan un evidente riesgo y que admiten métodos y soluciones alternativas" 74 .

En los casos de oposición de un adulto capaz a ciertos tratamientos médicos o en otros casos como los citados anteriormente, la utilización de la objeción de conciencia puede ser interesada. En el caso de un grupo que defienda sus creencias religiosas se consigue cierta publicidad con la consiguiente repercusión social, y otros supuestos, como el de la huelga de hambre citada, pueden estar alentados por motivaciones de índole política.

En el Derecho comparado, por último, se ha tomado en consideración para resolver determinados supuestos de oposición a tratamientos médicos de personas adultas la existencia o no de menores a cargo del sujeto así como su capacidad para decidir ${ }^{75}$; los poderes públicos deben permitir que el sujeto adopte la decisión que su conciencia le dicte siempre que no exista un interés predominante del Estado. Justificaría la intervención del Estado, la incapacidad del sujeto para decidir libremente o la existencia de menores a su cargo 76. Como exponemos a continuación, la intervención de los poderes públicos nos parece correcta en los casos de persona incapaz, pero no resulta tan clara la legitimidad de dicha intervención por la existencia de menores a cargo del que se opone a un determinado tratamiento médico. En nuestro Ordenamiento constitucional la obligación que la Constitución asigna a los padres en relación a la asistencia de todo orden a sus hijos (art. $39 \mathrm{CE}$ ), no parece implicar que el progenitor esté jurídicamente obligado a renunciar a uno o varios de sus derechos fundamentales - la obligación de asistencia no lo es-para cumplir con tal deber. Esta opinión ha sido avalada por la sentencia de la Audiencia Provincial de Huesca de 20 de noviembre de 1996 en la que se estima que los padres no están obligados a renunciar a sus creencias religiosas ni aunque peligre la vida de su hijo. Esta incipiente opinión jurisprudencial en nuestro país deberá, sin embargo, ser convalidada o rechazada por el Tribunal Supremo.

74 Navarro-Valls, R.: "Las objeciones de conciencia", en VV.AA.: Tratado de Derecho Eclesiástico, ob. cit., pág. 1138

75 Caso Matter of Melideo, de la Corte Suprema de Nueva York (1976). Esta y otras resoluciones en Navarro-Valls, R., Martinez Torrón, J.: Las objeciones de conciencia en el Derecho español y comparado, ob. cit., pág. 123.

76 lbídem. 


\section{III.3. Tratamientos médicos en persona adulta incapaz}

En el Derecho español, la falta de capacidad para manifestar el dictado de la conciencia impide, en mi opinión, la calificación del caso como un supuesto de objeción de conciencia, debiendo prevalecer la obligación del Estado de velar por el cumplimiento de los derechos y libertades, en este caso el derecho a la vida y a la integridad física del sujeto sobre la posible manifestación de personas distintas del sujeto. Esta tesis es especialmente sólida cuando la incapacidad ha sido declarada legalmente o cuando sin haberlo sido resulta tan evidente que impida igualmente la toma de decisiones libres; en ambos casos el Ordenamiento no debe otorgar, a nuestro juicio, relevancia jurídicas a las manifestaciones del sujeto.

En este sentido, no podemos desconocer que la Ley General de Sanidad reconoce el derecho del paciente a elegir entre las diversas terapias posibles, exigiendo, además, autorización escrita del mismo para realizar cualquier intervención y, "cuando no esté capacitado para tomar decisiones ... el derecho corresponderá a sus familiares o personas a él allegadas" (art. 10.6 , b); cabe también, que los familiares muestren su oposición al tratamiento en general, en cuyo caso, de conformidad con el artículo 10.9 de la citada Ley General de Sanidad deberán solicitar el alta voluntaria ${ }^{77}$.

Conforme a lo indicado ¿pueden los familiares de una persona incapaz negarse a un tratamiento médico concreto por razones de conciencia? Conforme a la tesis que venimos manteniendo debe darse una respuesta negativa a esta pregunta. Los familiares de un adulto incapaz no están facultados por el ordenamiento para actuar conforme a sus propias convicciones en asuntos que afecten a la salud o la vida del incapaz. Ello no podría enclavarse como un caso de objeción de conciencia pues, como ya dijimos, el carácter personalísimo de la misma impide que quien no posee discernimiento bastante sea representado por familiares o allegados aplicando sus propias convicciones.

77 El artículo 3.1 de la Ley 7/1985, de 5 de julio de Libertad Religiosa, establece como único límite de los derechos dimanantes de la libertad religiosa «... la salvaguardia de la seguridad, de la salud y de la moralidad pública, elementos constitutivos del orden público protegido por la Ley en el ámbito de una sociedad democrática». El término salud incorporado a este precepto se ha entendido por la doctrina como salud pública aunque la literalidad del precepto lo ponga en duda. Con todo, estimo correcta esta opinión puesto que la referencia a que tales elementos son constitutivos del orden público protegido por la Ley nos persuade de que, efectivamente, se refiere a la salud pública y no a la salud individual. 
Tampoco en estos casos cabe hablar, pues, de objeción de conciencia puesto que una persona incapaz ${ }^{78}$, no está sometida a los deberes jurídicos, de donde se sigue que es imposible que de su conciencia surja un conflicto opuesto a una norma jurídica de cuyo cumplimiento estará lógicamente exonerado por su condición de incapaz. Tampoco podrían oponerse sus tutores o representantes legales ya que, como venimos defendiendo, la objeción de conciencia sólo puede referirse al conflicto entre la conciencia individual y una norma jurídica, por tanto debemos concluir que los representantes legales de un incapaz no están legitimados para prestar el consentimiento necesario para rechazar una determinada terapia que puede poner en peligro la vida aquél, sí, sin embargo, al contrario, pues aceptando una terapia que, aun con riesgos, intente eliminar o disminuir el riesgo para la vida del paciente actúan en favor del derecho a la vida del sujeto que, como tales representantes, sí están obligados a depender.

Por otra parte, la formación de la conciencia individual requiere, como ya dijimos, discernimiento y madurez, elementos que suelen faltar en el caso que nos ocupa pero que también pueden estar sólo disminuidos. En los casos en que se dude acerca de la madurez o capacidad del sujeto para tomar una decisión de esta naturaleza, habrá que estar a la prueba que pueda realizarse $y$, en todo caso, a favor de la interpretación más favorable a la libertad del individuo, correspondiendo a la instancia judicial correspondiente la decisión final sobre el caso concreto.

En estos supuestos, no cabe sino actuar en favor de la vida del incapaz cualesquiera que sean las convicciones religiosas de los familiares 0 allegados a los que les corresponda, en su caso, otorgar las correspondientes autorizaciones.

Sin embargo, puede ocurrir que la imposibilidad de tomar una decisión individual no sea producto de una incapacidad permanente sino de una situación coyuntural (por ejemplo, la actuación médica ante una urgencia hospitalaria provocada por un accidente), en este caso no existe tampoco en el Ordenamiento jurídico dato alguno que permita que los familiares del enfermo suplan la decisión de éste favorable a poner en

78 Nos referimos en este comentario al sujeto jurídicamente incapaz. En los casos en los que la incapacidad no haya sido determinada jurídicamente o no se aprecie de manera evidente, habrá que estar a la previa determinación de las facultades mentales del sujeto para abordar la solución de un posible caso de objeción de conciencia. 
peligro su vida negándose a un determinado tratamiento médico aun conociendo que el enfermo profesa unas determinadas creencias religiosas que le vetarian el acceso a determinadas terapias, pues el enfermo puede optar por no cumplir los mandatos de su confesión ante el peligro para su salud o su vida, posibilidad que tendría si pudiera decidir y que no parece que deba ser cercenada por la decisión de personas ajenas al propio sujeto.

Es con todo, un supuesto más conflictivo pero la solución debe, en nuestra opinión, ser favorable a la eliminación del riesgo para la vida, puesto que, esta última especialmente, si se pierde no puede ser restituida.

\section{III.4. Tratamientos médicos en menores de edad}

Según lo que ya hemos afirmado, los menores de edad son titulares de determinados derechos y libertades constitucionales (derecho a la vida, a la integridad física y psíquica, derecho a la educación ...), tienen diferida dicha titularidad respecto de otros hasta su mayoría de edad (derecho de sufragio) o, también, aún siendo titulares de derechos concretos, pueden tener restringido el ejercicio de alguno de los aspectos del mismo en razón de su minoría de edad. Analicemos con mayor detalle el supuesto constitucional concreto.

Conforme al criterio favorable a la máxima extensión de los derechos que preside la interpretación en esta materia, no existe inconveniente para reconocer que los menores tienen reconocidas las libertades del artículo 16.1 de la Constitución aunque en los términos compatibles con su minoría de edad. ¿Qué significa esto? Si bien, como hemos indicado, determinados derechos requieren de manera expresa la mayoría de edad y ejercicio personal (así, por ejemplo, el mencionado derecho de sufragio), otros derechos y libertades quizá no requieran la mayoría de edad legal pero sí lógicamente, afirma R. SÁNCHEZ FERRIZ, una capacidad natural, que sería, por tanto, condición para la adquisición de la capacidad de obrar» ${ }^{79}$. En el supuesto que analizamos - tratamiento médico a menores de edad- los casos que, al menos, pueden plantearse son los siguientes:

79 Sánchez Ferriz, R.: Sobre las libertades, ob. cit., pág. 162. 
a) En asistencia hospitalaria

- Oposición personal de un menor de edad, alegando motivos religiosos o ideológicos, a que se le aplique un determinado tratamiento médico aun a riesgo de su vida.

- Oposición de los padres o tutores de un menor a que éste reciba un determinado tratamiento médico, alegando motivos religiosos o ideológicos, aun peligrando la vida del menor.

\section{b) Sin asistencia hospitalaria}

- Oposición del menor de edad o de sus padres o tutores a que reciba asistencia médica cuando así lo precise.

1. Oposición del menor en el marco de la asistencia hospitalaria

Respecto del primer supuesto ya hemos manifestado nuestra opinión acerca de la naturaleza jurídica de las objeciones de conciencia no reconocidas expresamente en la Constitución, debiendo encontrar su razón jurídica en formar o no parte del contenido esencial de las libertades reconocidas en el artículo 16.1 de la Constitución. Como hemos señalado igualmente, la doctrina suele inclinarse por considerar que aun siéndole reconocidas a un menor las libertades del artículo 16.1 citado, puede modularse el ejercicio de este derecho en función de la edad del sujeto. Así, «sólo quien tiene conciencia moral puede objetar» ${ }^{80}$, lo cual no soluciona el problema absolutamente sino que lo traslada a la determinación, en cada caso, de la existencia o no de dicha capacidad. Ya adelanto mi opinión contraria a que esta tesis se utilice de manera general, puesto que, si hasta la mayoría de edad, el menor está sometido a patria potestad es porque el Ordenamiento no lo considera plenamente capaz para decidir sobre las cuestiones más o menos esenciales de su vida, siendo así que resulta incongruente que no posea, por ejemplo, el derecho de sufragio y pueda el Ordenamiento jurídico considerar relevante y sin apelación posible una decisión que claramente ponga en peligro su vida.

80 Escobar Roca, G.: La objeción de conciencia en la Constitución Española, ob. cit., pág. 241. 
De otra parte, la minoría de edad es un elemento esencial en la regulación de un número muy amplio de supuestos contemplados pór el Ordenamiento jurídico ${ }^{81}$. En este sentido, el vigente Código Penal (art. 155), establece que no será válido el consentimiento otorgado por un menor de edad o un incapaz en los delitos de lesiones ${ }^{82}$.

En el marco de la asistencia hospitalaria debe presuponerse que el menor ha acudido voluntariamente y desea recuperar la salud y que su oposición lo es a una terapia concreta por motivos religiosos; siendo éste el supuesto, estimo, por lo expuesto en este y precedentes apartados, que la asistencia médica debe prestarse de conformidad con las creencias del paciente si ello fuera posible; en caso contrario, la regla general debe ser la de negar validez a la oposición del menor si tal negativa pone en peligro cierto su vida. No puede negarse, sin embargo, la posibilidad de algún caso en el que la minoría de edad esté a punto de expirar y el sujeto haya demostrado una madurez equiparable a la de un adulto, a cuyo supuesto resulta más difícil dar la misma solución, aunque, debe insistirse, en la excepcionalidad de esta hipótesis y en la conveniencia de que la regla general opere en favor del mantenimiento de la vida del sujeto.

En el ejemplo anteriormente expuesto, los familiares o allegados disporien de la facultad establecida en el artículo 10.6 y 9 de la Ley General de Sanidad, aunque su aplicación a los menores debe ser similar a la que consideramos adecuada al tratar de los sujetos incapaces, siendo preferible mantener que la objeción de conciencia o la oposición a determinados tratamientos médicos por razones de conciencia sólo puede ejercitarse por el sujeto plenamente capaz.

\section{Oposición de los padres o tutores}

Situación distinta de la anterior es aquella en el que son los padres los que se oponen directamente a que su hijo reciba ciertos tratamientos médicos.

81 El artículo 19 del Código Penal (Ley Orgánica 10/1995, de 23 de noviembre), establece que los menores de edad no serán responsables criminalmente con arreglo a dicho Código.

82 Artículo 155 del Código Penal y artículo 156 en lo relativo a trasplantes de órganos, esterilizaciones, etc. Sobre relevancia de la minoría de edad, ver también los artículos 181 (abusos sexuales), 187 (prostitución de menores), 224 (abandono del domicilio), 232 (mendicidad), 818 y 622 (abandono de menores) del Código Penal. 
El análisis constitucional de este supuesto requiere tomar en consideración los artículos 27.3 y 39.3 de la Constitución. Como sabemos, el artículo 27.3 reconoce el derecho fundamental de los padres a que sus hijos reciban la formación religiosa y moral que sea acorde con las convicciones de aquéllos ${ }^{83}$; el artículo 39.3, por su parte, se establece la obligación de los padres de prestar asistencia de todo orden a sus hijos ${ }^{84}$.

En relación con el derecho fundamental de los padres a que sus hijos se formen en las convicciones religiosas y morales que ellos mismos consideren oportunas ${ }^{85}$, estimamos que tal manifestación constitucional persigue garantizar a los padres o tutores que el Estado no está facultado para imponer la enseñanza de una determinada confesión religiosa, lo cual, por otra parte, sería redundante respecto de la declaración del artículo 16.3 de la Constitución cuando afirma que ninguna confesión tendrá carácter estatal; conforme a esta tesis, el artículo 27.3 no avalaría el derecho de los padres a impedir la libre manifestación de las convicciones por parte de los hijos, prevaleciendo, en caso de conflicto, la opinión de éste ${ }^{86}$.

Creo que, sin apartamos esencialmente de la opinión anterior, la interpretación que debe darse al artículo 27.3 no pasa por negarle su virtualidad como derecho fundamental de los padres respecto de la formación de sus hijos sino, antes al contrario, insistir en tal carácter de derecho fundamental aunque delimitando el alcance a lo que la Constitución realmente establece: a saber, que los padres tienen derecho a decidir con plena autonomía la formación religiosa y moral que deben recibir sus hijos aunque ello no implica que el hijo deba seguir y cumplir los ritos de la confesión religiosa elegida por sus padres ni acomodar su voluntad a las convicciones

83 El artículo 27.3 de la Constitución dice: «Los poderes públicos garantizan el derecho que asiste a los padres para que sus hijos reciban la formación religiosa y moral que esté de acuerdo con sus propias convicciones".

84 El artículo 39.3 de la Constitución establece: «Los padres deben prestar asistencia de todo orden a los hijos habidos dentro o fuera del matrimonio, durante su minoría de edad y en los demás casos en que legalmente proceda".

85 La Ley de Libertad Religiosa ha recogido también esta posibilidad, en el artículo 2.1.c), al garantizar a toda persona el derecho a:

«Recibir e impartir enseñanza e información religiosa de toda índole, ya sea oralmente, por escrito o por cualquier otro procedimiento; elegir para sí y para los menores no emancipados e incapacitados, bajo su dependencia, dentro y fuera del ámbito escolar, la educación religiosa y moral que esté de acuerdo con sus propias convicciones".

86 Escobar Roca, G.: La objeción de conciencia,en la Constitución Española, ob. cit., pág. 243. 
morales de sus progenitores o de sus tutores y ello cualquiera que sea el grado de formación o desarrollo de la conciencia del hijo. Conforme a esta opinión que considero correcta, no se trata tanto de que, en el caso de que sean dispares, las convicciones del hijo deban prevalecer sobre las de los padres sino de que el derecho fundamental de éstos no comprende el ejercicio efectivo de la religión por el hijo.

Así, el contenido esencial del derecho consagrado en el artículo 27.3 de la Constitución es la facultad de decidir sobre el contenido de la formación religiosa y moral que ha de recibir el menor y el sujeto de este derecho fundamental es la madre y/o padre o, en su caso, los tutores o guardadores legales. Este derecho no implica, conviene insistir en ello, obligación alguna del hijo que exceda de la de recibir, como sujeto pasivo, las enseñanzas decididas por sus progenitores; no queda obligado, pues, el menor a ninguna acción ni conducta positiva acorde con dicha instrucción. Hasta aqui la interpretación que creo correcta del artículo 27.3 de la Constitución.

Por otro lado, el artículo 39.3 de la Constitución establece la obligación de los padres de prestar asistencia de todo orden a sus hijos menores y a los mayores de edad cuando legalmente proceda ${ }^{87}$. Al contrario de lo que sucede en el artículo 27.3 CE antes citado, el artículo 39.3 consagra un deber constitucional que obliga a los padres a prestar asistencia material a sus hijos ${ }^{88}$. Este deber constitucional ha sido desarrollado por la legislación civil y penal. Respecto de la primera de ellas, el artículo 154.2 del Código Civil establece las obligaciones básicas inherentes a la patria potestad, que se ejercerá siempre en beneficio del hijo, de acuerdo con su personalidad, y que comprende los siguientes deberes y facultades:

“ $1^{\circ}$. Velar por ellos, tenerlos en su compañía, alimentarlos, educarlos y procurarles una formación integral.

\section{$2^{\circ}$. Representarlos y administrar sus bienes".}

En cuanto a la legislación penal, el artículo 226 del Código Penal tipifica el abandono de familia, menores o incapaces estableciendo que el «que dejare de cumplir los deberes legales de asistencia inherentes a la patria

87 El artículo 39.3 de la Constitución literalmente dice: «Los padres deben prestar asistencia de todo orden a los hijos habidos dentro o fuera del matrimonio, durante su minoría de edad y en los demás casos en que legalmente proceda".

88 GómEZ, Y.: Familia y matrimonio en la Constitución Española de 1978, Congreso de los Diputados, Madrid, 1990, pág. 336. 
potestad, tutela, guarda o acogimiento familiar ... será castigado con la pena de arresto ...".

Tal y como venimos manifestando, la objeción de conciencia, en tanto conflicto íntimo y personal del sujeto con un mandato o norma imperativa, exige que sea el propio sujeto el que, efectivamente, la manifieste toda vez que el dictado de la conciencia no se supone y ello debe ser asi por las graves implicaciones que para la vida y la integridad física del hijo representan estos casos. La tutela de estos derechos le corresponde al Estado pero, en primera instancia, a los padres a través de las obligaciones inherentes a la patria potestad a las que antes se aludió.

En un caso reciente, aun pendiente de resolución definitiva por el Tribunal Supremo, la Audiencia provincial de Huesca ha absuelto a los padres de un menor fallecido, los tres miembros de los Testigos de Jehová, tras la negativa tanto de éste como de los padres a que se realizara una necesaria transfusión de sangre, estimando que los padres no están obligados a renunciar a sus convicciones religiosas ni siquiera ante el peligro para la vida de su hijo y que tampoco están obligados a convencer al hijo para que se someta a este tratamiento. En este caso, el personal sanitario -incorrectamente a mi juicio- intentó convencer infructuosamente al menor para que diera su conformidad a la transfusión de sangre ${ }^{89}$, cuando hubiera bastado, a mi juicio, amparar tal tratamiento en la obligación de los poderes públicos de tutelar los derechos fundamentales (en este caso la vida del menor) de conformidad con lo preceptuado en el artículo $10.6 \mathrm{c}$ ) de la Ley General de Sanidad -peligro para la vida del paciente - ${ }^{90}$ o bien haber transferido la responsabilidad a los padres, de conformidad con lo establecido en el apartado b) del citado artículo 10.6 de la Ley General de Sanidad, la negativa de los cuales debería haber sido entendida como un incumplimiento de los deberes inherentes a la patria potestad, con posibles implicaciones penales ${ }^{91}$, puesto que si bien los padres no están obligados a renunciar a sus propias convicciones

89 Sentencia de la Audiencia Provincial de Huesca, de 20 de noviembre de 1996, cfr. NAvaRro Valls, R.; Martínez ToRRón, J.: Las objeciones de conciencia en el Derecho español y comparado, ob. cit., pág. 123.

90 El artículo 10.6. c) de la Ley General de Sanidad establece que el paciente tiene derecho a elegir entre las distintas opciones que le presenten los médicos, siendo precisa autorización escrita para cualquier intervención salvo:

«c) Cuando la urgencia no permita demoras por poderse ocasionar lesiones irreversibles o existir peligro de fallecimiento".

91 Ver artículos 10, 11 y 226 del Código Penal. 
religiosas - tal y como se afirma en esta sentencia - es igualmente cierto que sus obligaciones de tutela y asistencia al hijo están legalmente establecidas y no poseen, como ya dijimos, un derecho a que el hijo practique las convicciones de los padres ni, como igualmente hemos señalado, puede ser relevante la manifestación del hijo cuando se encuentre en peligro de muerte.

\section{III.5. Asistencia hospitalaria conforme a distintas conviciones religiosas}

Asunto distinto del tratado hasta ahora, es el de si un hospital u organización sanitaria pública está obligado a disponer de medios terapéuticos alternativos para asistir a pacientes que, por ejemplo, se opongan a recibir transfusiones de sangre. Este supuesto ha sido resuelto por el Tribunal Constitucional en la Sentencia 166/1996, de 28 de octubre, que puso fin al recurso de amparo presentado por un paciente, miembro de los Testigos de Jehová, que consideraba violada su libertad religiosa y el principio de igualdad, por lo que reclamaba al Estado el pago de las prestaciones sanitarias realizadas a un hospital privado al que tuvo que trasladarse ya que en el hospital público donde fue operado se le practicó con su oposición pero con autorización judicial una transfusión de sangre y le anunciaron la necesidad de realizar otras posteriores.

El Tribunal Constitucional, en primer término, recuerda que, como ya tiene establecido en resoluciones anteriores, "el carácter público y la finalidad constitucionalmente reconocida del sistema de la Seguridad Social supone que éste se configure como un régimen legal, en el que tanto las aportaciones de los afiliados, como las prestaciones a dispensar, sus niveles y condiciones, vienen determinados, no por un acuerdo de voluntades, sino por reglas que se integran en el ordenamiento jurídico" 92. En segundo lugar, como igualmente ha establecido el propio Tribunal, la libertad religiosa, entendida como un derecho subjetivo de carácter fundamental, implica un ámbito de libertad y una esfera de agere licere del individuo, es decir, reconoce el derecho de los ciudadanos a actuar con plena inmunidad de coacción del Estado, de personas o grupos, sin perjuicio de que el propio Estado quede obligado a adoptar las medidas 
necesarias para que dicha libertad sea posible, pero, como señala el mismo Tribunal Constitucional, "de estas obligaciones del Estado y de otras tendentes a facilitar el ejercicio de la libertad religiosa no puede seguirse, porque es cosa distinta, que esté también obligado a otorgar prestaciones de otra índole para que los creyentes de una determinada religión puedan cumplir los mandatos que les imponen sus creencias" ${ }^{93}$; tal cosa, como ya se señaló por el Tribunal, supondría «una excepcionalidad, que, aunque pudiera estimarse como razonable, comportaria la legitimidad del otorgamiento de esta dispensa del régimen general, pero no la imperatividad de su imposición» ${ }^{94}$.

El Tribunal concluye, además, que, en este caso, no se produjo vulneración del principio de igualdad ya que el mismo impide la discriminación pero no faculta al particular para imponer o exigir determinadas diferencias de trato ${ }^{95}$. El Magistrado J.D. GONZÁLEZ CAMPOS formuló un voto particular a esta sentencia defendiendo que debió otorgarse el amparo solicitado por el recurrente, ya que éste no había solicitado una prestación sanitaria a la que no tuviera derecho, sino ser atendido de manera que no se vulneraran sus creencias religiosas siendo posible —añade el Magistrado- que tal asistencia fuera prestada en esas condiciones (en este caso, sin transfusión de sangre).

Aun aceptando plenamente el razonamiento del Tribunal Constitucional en este caso, no debemos desconocer que, como ya hemos señalado, el Estado está obligado a promover las condiciones necesarias para la plena eficacia de los derechos sin que, en muchos casos, la mera abstención satisfaga tal exigencia. Por otro lado, la Ley de Libertad Religiosa establece la obligación de los poderes públicos de adoptar las medidas necesarias para la plena eficacia de los derechos contenidos en esta Ley, con referencia expresa a los establecimientos hospitalarios ${ }^{96}$. A la luz de las normas constitucionales y legales, la posición mantenida en el voto particular no es desdeñable en absoluto y las demandas en este sentido pueden evolucionar en el futuro y exigirse que, dentro de la ponderación de

93 STC 166/1996, de 28 de octubre.

94 STC 19/1985, de 13 de febrero.

95 Entre otras muchas, STC 114/1995, de 6 de julio.

96 El artículo 2.3 de la Ley de Libertad Religiosa establece:

«Para la aplicación real y efectiva de estos derechos, los poderes públicos adoptarán las medidas necesarias para facilitar la asistencia religiosa en los establecimientos públicos militares, hospitalarios, asistenciales, penitenciarios, y otros bajo su dependencia, así como la formación religiosa en centros docentes públicos." 
bienes y recursos en juego, la sanidad pública ofrezca terapias alternativas para este tipo de pacientes.

\section{LA OBJECIÓN DE CONCIENCIA A TRATAMIENTOS MÉDICOS EN SITUACIONES DE RIESGO COLECTIVO}

Por otro lado, aunque el caso de los Testigos de Jehová es quizá uno de los más conocidos, las vertientes de este problema no han hecho sino comenzar, puesto que la negativa a recibir determinados tratamientos médicos puede esgrimirse también en el caso de tratamientos preventivos -como las vacunas- cuyas consecuencias podrían afectar a amplias capas de población. Como bien han señalado R. NAVARRO-VALLS y J. MARTíNEZ TORRÓN, las peculiaridades de estos supuestos exceden el ámbito estricto de la libertad religiosa y de conciencia e inciden de manera sustancial en el contenido de otros derechos constitucionales (derecho a la vida, derecho a la intimidad ...) y también con principios como el deber del Estado de preservar la vida y la salud de los ciudadanos y el de los profesionales de la medicina de respetar el juramento hipocrático ${ }^{97}$.

Puede, sin embargo, presentarse un supuesto en el que el tratamiento médico no vaya dirigido a impedir la muerte del sujeto o a mejorar sustancialmente su vida, sino que se trate de unas medidas de política sanitaria general. En este caso, estimo que el Estado está facultado para imponer determinadas medidas necesarias para mantener unas condiciones generales de supervivencia que podrian verse amenazas por circunstancias específicas, ello además de la obligación de tutela positiva que le corresponde a los poderes públicos en orden a la eficacia de los derechos fundamentales a la que antes ya se aludió.

La Constitución española recoge en varios de sus preceptos las obligaciones de los poderes públicos en cuanto a la protección de bienes colectivos, entre ellos, la salud, así como la posibilidad de que mediante ley se establezcan deberes a los ciudadanos de igual carácter o para la protección de intereses generales.

97 Navarro-Valls, R. y Martínez Torrón, J.: Las objeciones de conciencia en el Derecho español y comparado, McGraw-Hill, Madrid, 1997, pág. 121. 
1. El Estado social y democrático de Derecho en el que España se constituye (art. 1.1 CE) enmarca estas obligaciones tanto de los poderes públicos como de los particulares, pues es ampliamente aceptado que tal fórmula no se agota en los aspectos jurídico-formales sino que persigue una verdadera transformación de la sociedad para la consecución de una mayor calidad de vida.

2. Por otro lado, el artículo 30.4 de la Constitución establece que mediante «ley podrán regularse los deberes de los ciudadanos en los casos de grave riesgo, catástrofe o calamidad pública".

3. Por su parte, el artículo 43 de la Constitución, que incide directamente en el aspecto del que tratamos, reconoce el derecho a la protección de la salud y asigna a los poderes públicos la competencia para organizar y tutelar la salud pública, adoptando las medidas necesarias para ello. Termina este precepto establecimientos que la «ley establecerá los derechos y deberes de todos al respecto" 98 .

Con esta base constitucional la Ley Orgánica $7 / 1985$, de 5 de julio, de Libertad Religiosa establece como uno de los límites del ejercicio de las libertades a las que se refiere dicha Ley, la salud ${ }^{99} y$, en igual sentido, la Ley General de Sanidad ha desarrollado el derecho a la protección de la salud ${ }^{100}$, estableciendo los derechos y deberes de los usuarios de la sanidad. A estos efectos, recordemos que, el ya citado, artículo 10 de esta Ley establece que todos los usuarios tienen derechos a:

98 Los apartados 1 y 2 del artículo 43 de la Constitución establecen:

«1. Se reconoce el derecho a la protección de la salud.

2. Compete a los poderes públicos organizar y tutelar la salud pública a través de medidas preventivas y de las prestaciones y servicios necesarios. La ley establecerá los derechos y deberes de todos al respecto.»

99 El artículo 3.1 de la Ley de Libertad Religiosa establece:

«El ejercicio de los derechos dimanantes de la libertad religiosa y de culto tiene como único límite la protección del derecho de los demás al ejercicio de sus libertades públicas y derechos fundamentales, así como la salvaguardia de la seguridad, de la salud y de la moralidad pública, elementos constitutivos del orden público protegido por la Ley en el ámbito de una sociedad democrática".

100 Así se declara en el artículo 1, apartados 1 y 2 de la Ley 14/1986, de 25 de abril, General de Sanidad, que literalmente dice:

«1. La presente Ley tiene por objeto la regulación general de todas las acciones que permitan hacer efectivo el derecho a la protección de la salud reconocido en el artículo 43 y concordantes de la Constitución.

2. Son titulares del derecho a la protección de la salud y a la atención sanitaria todos los españoles y los ciudadanos extranjeros que tengan establecida su residencia en el territorio nacional». 
"...

5. A que se le dé en términos comprensibles a él y a sus familiares o allegados, información completa y continuada, verbal y escrita, sobre su proceso, incluyendo diagnóstico, pronóstico y alternativas de tratamiento.

6. A la libre elección entre las opciones que le presente el responsable médico de su caso, siendo preciso el previo consentimiento escrito del usuario para la realización de cualquier intervención, excepto en los siguientes casos:

a) Cuando la no intervención suponga un riesgo para la salud pública.

b) Cuando no esté capacitado para tomar decisiones, en cuyo caso el derecho corresponderá a sus familiares o personas a él allegadas.

c) Cuando la urgencia no permita demoras por poderse ocasionar lesiones irreversibles o existir peligro de fallecimiento.

9. A negarse al tratamiento, excepto en los casos señalados en el apartado 6, debiendo para ello solicitar el alta voluntaria, en los términos que señala el apartado 4 del artículo siguiente».

Continúa la ley estableciendo las obligaciones de los ciudadanos con las instituciones y organismos del sistema sanitario y, el artículo 11.1, establece que una de tales obligaciones es "cumplir las prescripciones generales de naturaleza sanitaria comunes a toda la población, así como las específicas determinadas por los servicios sanitarios".

Conforme a todo ello, parece que, en el caso de oposición a tratamientos médicos en el marco de programas de política sanitaria general o ante una situación de urgencia sanitaria de carácter general, sí puede darse el supuesto de objeción de conciencia - hay norma de carácter general y puede existir oposición de la conciencia individual- y aunque habrá que tomar en cuenta, sin duda, la gravedad del supuesto el derecho a la salud de la colectividad no deberia ponerse seriamente en peligro por la oposición individual. Siempre que sea posible debe optarse por arbitrar medidas alternativas (aislamiento, terapia alternativa, etc.), que impidan el conflicto entre la norma general y la conciencia individual, de lo contrario, es jurídicamente posible hacer prevalecer la tutela de la salud colectiva sobre el dictado de la conciencia individual.

Así, en caso de grave riesgo para la salud colectiva, los poderes públicos encuentran en la Constitución la base suficiente para limitar la objeción de conciencia del sujeto al que asisten las libertades del artículo 16.1 justo hasta donde sean posibles sin perturbar los derechos de los demás (derecho a la vida, a la integridad física y psíquica, el derecho a la salud ..) ni otros bienes jurídicamente protegidos. 
Además, de lo señalado anteriormente, la propia Constitución establece la posibilidad de que el Gobierno declare el estado de alarma (art. 116.2) cuando se produzcan crisis sanitarias como epidemias o situaciones de contaminación graves ${ }^{101}$. Es conocida la escasa utilización que los Gobiernos hacen de este tipo de institutos, ya que se prefieren dar solución a los problemas en el marco de la normalidad constitucional. Con todo, no puede obviarse esta posibilidad que, en nuestro Derecho, permitiría una salida jurídica acorde con la Constitución para los supuestos en los que, existiendo una grave amenaza para la salud pública, un grupo de riesgo se negara a adoptar las medidas preventivas o reparadoras necesarias, ya que la declaración del estado de alarma permite adoptar una serie de medidas como la limitación de la circulación de personas y vehículos o intervenir y ocupar transitoriamente industria, fábricas, talleres y, específicamente, se establece, en el artículo 12.1 de la Ley Orgánica Reguladora de los Estados de Alarma, Excepción y Sitio, que la "Autoridad competente podrá adoptar por sí, según los casos, además de las medidas previstas en los artículos anteriores, las establecidas en las normas para la lucha contra las enfermedades infecciosas, la protección del medio ambiente, en materia de aguas y sobre incendios forestales». Esta posibilidad constitucional representa un límite a la libre disposición del propio cuerpo y a la denominada objeción de conciencia a tratamientos médicos que, aun en sentido impropio, debe quedar reducida a aquellos casos en los que la salud pública no este gravemente amenazada. Es misión del Gobierno, en ejercicio de sus competencias de dirección política (art. $97 \mathrm{CE}$ ), determinar las medidas que deben adoptarse ante una situación de crisis sanitaria y, en su caso, cuándo es necesario adoptar la, sin duda grave, medida de la declaración del estado de alarma.

101 El artículo 4, de la Ley Orgánica 4/1981, de 1 de Junio, Reguladora de los Estados de Alarma, Excepción y Sitio, establece:

«El Gobierno, en uso de las facultades que le otorga el artículo 116.2 de la Constitución podrá declarar el estado de alarma, en todo o parte del territorio nacional, cuando se produzca alguna de las siguientes alteraciones graves de la normalidad:

a) Catástrofes, calamidades o desgracias públicas, tales como terremotos, inundaciones, incendios urbanos y forestales o accidentes de gran magnitud.

b) Crisis sanitarias, tales como epidemias y situaciones de contaminación graves.

c) Paralización de servicios públicos esenciales para la comunidad, cuando no se garantice lo dispuesto en los artículos 28.2 y 37.2 de la Constitución, y concurra alguna de las demás circunstancias o situaciones contenidas en este artículo.

d) Situaciones de desabastecimiento de productos de primera necesidad". 